\title{
SPATIAL DISTRIBUTION, POLLUTION, AND HEALTH RISK ASSESSMENT OF HEAVY METAL IN INDUSTRIAL AREA SOILS OF ULAANBAATAR, MONGOLIA
}

\author{
P. Oyunbat ${ }^{1,2^{*}}$, O. Batkhishig ${ }^{1}$, B. Batsaikhan ${ }^{1}$ F. Lehmkuhl ${ }^{3}$, M. Knippertz ${ }^{3}$, V. Nottebaum ${ }^{3}$ \\ ${ }^{1}$ Institute of Geography and Geoecology, Mongolian Academy of Sciences, Ulaanbaatar - 15170, Mongolia \\ Purevsuren.Oyunbat@gmail.com, batkhishig@gmail.com, bayartungalag_b@mas.ac.mn \\ ${ }^{2}$ National University of Mongolia, University Street 1, Ulaanbaatar - 14201, Mongolia \\ ${ }^{3}$ RWTH Aachen University, Wullnerstr, 5b - 52062 Aachen, Germany
}

KEY WORDS: Spatial distribution, Heavy metal, Soil pollution, Health risk assessment, Ulaanbaatar

\begin{abstract}
:
The heavy metal pollution of urban soil of industrial area and its impact on human healths becoming one of the environmental problems in Ulaanbaatar city of Mongolia. The purpose of this study was to determine spatial distribution and health risk of heavy metal pollution in soils surrounding area of leather processing factory and wastewater treatment plants (WWTP) of Ulaanbaatar city. Mapping the spatial distribution of contaminants in soils is the basis of pollution evaluation and risk control. Interpolation methods are extensively applied in the mapping processes to estimate the heavy metal ( $\mathrm{As}, \mathrm{Zn}, \mathrm{Pb}, \mathrm{Cd}, \mathrm{Cr}, \mathrm{Cu}$ ) concentrations of topsoils. The average concentrations of $\mathrm{Cr}, \mathrm{Ni}, \mathrm{Pb}, \mathrm{Zn}, \mathrm{Cu}$ and $\mathrm{As}$ were 1986.9, 110.5, 111.0, 110.5, 53.5, $16.4 \mathrm{mg} / \mathrm{kg}$, respectively. According to result as the soil pollution index with spatial distribution, a high pollution level for $\mathrm{Cr}$ while $\mathrm{Zn}, \mathrm{Cu}$ and $\mathrm{Pb}$ have medium pollution levels. The soil pollution index (PI) values of heavy metals of study areas are, following descending orders $\mathrm{Cr}>$ $\mathrm{Zn}>\mathrm{Cu}>\mathrm{Pb}>\mathrm{As}>\mathrm{Ni}$. The potential ecological risk of $\mathrm{Cr}, \mathrm{Cu}, \mathrm{Pb}$, As indicated high ecological risk in the study area. The Hazard index values for almost all the metals were higher than 1, it is indicating a carcinogenic risk for children and adults. The risk index values of two metals (Cr, As) were contribute to a higher risk of development of cancer in humans. Heavy metal contamination can occur when soil particles are swept away from the initial pollution areas by the wind. Therefore, it is necessary to take measures to reduce soil pollution and encourage rehabilitation.
\end{abstract}

\section{INTRODUCTION}

Heavy metals are one of the main sources of environmental pollution: they are dangerous for human health and the quality of the surrounding environment. They can affect biochemical cycles and accumulate within living organisms. Since they are non-degradable by physical processes, they have the ability to persist for a long time. Heavy metals in urban soils are very useful indicators of environmental pollution (Manta et al., 2002) (Batjargal et al., 2011). Many studies have indicated that urban soils are contaminated by heavy metals and this phenomenon has been attributed mainly to modern industries, traffic and mining activities in urban areas (Gallagher et al., 2008). The abundance of contamination sources in urban systems results in chemical pressures that often manifest as high pollution concentrations or loadings (Wong et al., 2006), which consequently have detrimental impacts on human and ecosystem health (Taylor \& Owens, 2009). In urban areas, these heavy metals have become a potential threat to human health and have severely disturbed the natural geochemical cycling of the ecosystem. Furthermore, metals have a direct influence on human health, as they can easily enter human bodies through dust ingestion, dermal contact, or inhalation. Many studies have indicated that toxic metals can accumulate in fatty tissues, affecting the functions of organs and disrupting the nervous system or endocrinal system (Shi et al., 2008) (Jaishankar et al., 2014). Some heavy metals (As, Pb, Cr, Cd, $\mathrm{Hg}$ ) can also interact directly with DNA to cause mutations; such damage to the cells, if not treated immediately, can induce carcinogenesis (Ying et al., 2016).

Due to the rapid growth of Ulaanbaatar, environmental conditions are worsening and soil, water and air pollution threaten the lives of residents. According to previous research (Erdenesaikhan, et al. 2017) (Batkhishig, et al., 2018) in some areas of the capital city, high chromium, lead and zinc content was found in the soil, exceeding the national standard (Mongolian standard for toxic chemicals in soil, 2019), such as in the leather processing factory area of the Khan Uul district, several auto service repair points and some solid waste areas of the Ger districts. One of the major sources of heavy metals pollution in Ulaanbaatar soil is leather processing factories and their wastewater treatment plant. The wastewater treatment plant was established in 1972 to remove and dispose of wastewater from the leather and wool processing factories. Due to the lack of technological renovation, the equipment was worn and the sewage drainage system became obsolete. Technological discharges from the plants flowed into the streets. In addition, chemical pollution of the soil, which can harm the environment and human health, is caused by the unhealthy activities of the leather processing, the chemicals used, the resulting products, as well as the standards and procedures for transport, storage and use. The leather processing factories use a variety of chemicals, including sulphate chromium $\left[\mathrm{Cr}_{2}\left(\mathrm{SO}_{4}\right)^{3}\right]$ for the development of skin tanning and paint. The metal in the industrial environment is dependent on vegetation cover, landscape and weather conditions (Nriagu, 1988). Chromium-containing waste and sludge particles are transported into the environment by water and wind (Zhu \& Qi, 2007).

Chromium VI is the most dangerous form of chromium and can cause health problems including allergic reactions, skin rash, nose irritations and nosebleed, ulcers, weakened immune system, genetic material alteration, kidney and liver damage, and may even go as far as causing the death of the individual. Finally, $\mathrm{Cr}$ (VI) is a known human carcinogen and has a high toxicity reference value. Chromium found in soil most commonly exists in both the trivalent (Cr (III)) and hexavalent (Cr (VI)) forms. When $\mathrm{Cr}$ (III) resides in highly acidic soil with 
$\mathrm{pH}$ 2.7-4.5, the soil humus is absorbed into the acid and becomes insoluble, immobile and inactive (Asfaw et al., 2017). Absorption of $\mathrm{Cr}(\mathrm{VI})$ in neutral and alkaline $(\mathrm{pH}>6.8)$ soil resides in a low to medium soluble state (ex. Sodium chromate [ $\left.\mathrm{Na}_{2} \mathrm{CrO}_{4}\right]$, barium chromate $\left[\mathrm{BaCrO}_{4}\right]$, and lead (II) chromate $[\mathrm{PbCrO} 4])($ Bartlett and Kimble, 1976).

In this highly polluted area living 6996 peoples (1749 families) in 2018. There is a kindergarten, a school, a food market, and other service organizations. The residents complained to the Government of Ulaanbaatar about dust, allergic reactions and respiratory illness from the activities of the treatment plants and leather processing factories. Heavy metal pollution in soil is caused by wind and vehicle movements, and can cause harm to human health. Based on these situations, parliament decided to relocate treatment plants and leather processing factories on December 31, 2017, from Ulaanbaatar (Decision 74 of the Mongolian Parliament, 2012). However, waste treatment plants and leather factories are still operational. There is a lack of research results estimating adverse environmental and negative human health impacts from treatment facilities and leather factories. Therefore, this study is very important for the assessment and distribution analysis of heavy metal soils and to determine human health risk assessment in wastewater plants (WWTP) and leather factories. In addition, the soil quality, climatic conditions and land use characteristics need to be identified along with the technology to rehabilitate contaminated soils.

\section{METHODS AND MATERIAL}

\subsection{Soil sampling and Laboratory analysis}

For the soil sampling used grid method (25-50 meters) and surface soils with a depth of $0-10 \mathrm{~cm}$. The soil samples were analyzed for $\mathrm{pH}$, organic matter, electrical conductivity (EC), texture and 33 heavy metals $(\mathrm{Cr}, \mathrm{As}, \mathrm{Cd}, \mathrm{Ni}, \mathrm{Cu}, \mathrm{Pb}, \mathrm{Zn}$, etc.). The heavy metals of the soil were determined using the ICP40B, Optical Spectrometer (OS) method. General chemical properties of the soil were determined in the Soil Laboratory of the Institute of Geography and Geoecology of the Mongolian Academy of Sciences. The following methods were used: $\mathrm{pH}$ potentiometer $(\mathrm{H} 2 \mathrm{O}, 1: 2.5)$, calcium carbonate $\left(\mathrm{CaCO}_{3}\right)$ volumetric and conductivity (EC).

\subsection{Pollution index (PI and PLI)}

The pollution level of heavy metals in soils was evaluated using the pollution index (PI), and the potential ecological risk (PER) (Chen et al., 2015) (Islam et al., 2015) (Moghtaderi et al., 2018). The pollution index (PI) was defined as the ratio of element concentration in the soil sample to the background concentration of the corresponding element in the Mongolian soil (Ulaanbaatar). The PI of each element was calculated and classified as either low $(\mathrm{PI} \leq 1)$, middle $(1<\mathrm{PI} \leq 3)$ or high (PI $>3$ ) (Chen et al., 2015). In addition, to give an assessment of the overall pollution status for a sample, the pollution load index (PLI) of heavy metals was calculated using

$$
\mathrm{PLI}=\left(\mathrm{PI}_{1} \times \mathrm{PI}_{2} \times \mathrm{PI}_{3} \times \ldots \times \mathrm{PI}_{n}\right)^{1 / \mathrm{n}}
$$

According to the contamination degree, the PLI classifies into categories unpolluted (PLI $\leq 1)$, unpolluted to moderately polluted $(1 \leq \mathrm{PLI} \leq 2)$, moderately polluted $(2 \leq \mathrm{PLI} \leq 3)$, moderately to highly polluted $(3 \leq \mathrm{PLI} \leq 4)$, highly polluted (4 $\leq \mathrm{PLI} \leq 5)$, or very highly polluted (PLI $>5$ ) (Chen et al., 2015).

\subsection{Potential ecological risk (PER)}

The potential ecological risk index (PER), proposed by Hakanson (1980), based on elemental abundance and release capacity, was introduced to assess the degree of heavy metal pollution in soils, according to the toxicity of heavy metals and the response of the environment (Chen et al., 2015).The PER was estimated as follows:

$$
\begin{aligned}
& \text { PER }=\sum_{\mathrm{i}}^{\mathrm{n}} \mathrm{E}_{\mathrm{j}}^{\mathrm{i}} \\
& \mathrm{E}_{\mathrm{j}}^{\mathrm{i}}=\mathrm{T}_{\mathrm{n}}^{\mathrm{i}} \times \mathrm{C}_{\mathrm{i}}^{\mathrm{j}} \\
& \mathrm{C}_{\mathrm{j}}^{\mathrm{i}}=\mathrm{c}^{\mathrm{i}} / \mathrm{C}_{\mathrm{j}}^{\mathrm{j}}
\end{aligned}
$$

Where $\mathrm{C}_{1}^{\mathrm{j}}$ means the pollution factor of heavy metal $i$. $\mathrm{C}^{\mathbf{1}}$ is the measured concentration of heavy metal $i$ in the sample and $\mathrm{C}_{\mathrm{n}}^{1}$ is the background value of heavy metal $i$ (Table 3). $\mathrm{E}_{j}^{\tilde{1}}$ stands for the potential ecological risk index of a single element. $T_{n}^{I}$ is the biological toxic factor for heavy metal $i$. The toxic response factors for $\mathrm{Cr}, \mathrm{Ni}, \mathrm{Cu}, \mathrm{As}, \mathrm{Cd}$ and $\mathrm{Pb}$ are 2, 6, 5, 10, 30 and 5, respectively. The degree of ecological risk can be categorized as follows: $\mathrm{E}_{\mathfrak{j}}^{1}<40$; low risk, $40 \leq \mathrm{E}_{\mathfrak{1}}^{\mathrm{i}} \leq 80$; moderate risk, $80 \leq \mathrm{E}_{\mathrm{i}}^{\mathrm{i}}$ $\leq 160$; considerable risk, $160 \leq \mathrm{E}_{\mathfrak{j}}^{\hat{1}} \leq 320$; high risk and $\mathrm{E}_{\mathfrak{j}}^{\hat{1}} \geq$ 320; very high risk (Hakanson, 1980).

\subsection{Human health risk assessment}

2.4.1 Quantity of exposure calculation: Health risk assessment of urban topsoil is widely used to quantify both carcinogenic and non-carcinogenic risks to human via three exposure pathways: ingestion, dermal contact, and inhalation. The methodology used for the health risk assessment was based on the guidelines and Exposure Factors Handbook of US Environmental Protection Agency ( EPA, 1986, \{Formatting Citation\}, (U.S. EPA, 2011), (EPA, 2001). The average daily doses (ADD) (mg/kg-day) of potentially toxic metals via ingestion (ADD ing), dermal contact (ADD derm) and inhalation (ADD inh) for both adults and children were estimated using Eqs. (3-5)

$$
\begin{aligned}
& \mathrm{ADD}_{\text {ing }}=[(\mathrm{Cs} \times \mathrm{IngR} \times \mathrm{EF} \times \mathrm{ED}) /(\mathrm{BW} \times \mathrm{AT})] \times 10^{-6} \\
& \mathrm{ADD}_{i n h}=(\mathrm{Cs} \times \mathrm{IngR} \times \mathrm{EF} \times \mathrm{ED}) /(\mathrm{PEF} \times \mathrm{BW} \times \mathrm{AT}) \\
& \mathrm{ADD}_{\text {dermal }}=[(\mathrm{Cs} \times \mathrm{SA} \times \mathrm{SL} \times \mathrm{ABS} \times \mathrm{EF} \times \mathrm{ED}) /(\mathrm{BW} \times \mathrm{AT})] \\
& \times 10^{-6}
\end{aligned}
$$

Where ADD ing, ADD derm and ADD inh are the daily amounts of exposure to metals ( $\mathrm{mg} / \mathrm{kg}$-day) via ingestion, dermal contact, and inhalation, respectively. Other exposure factors and values used to estimate the intake value and risk are given in Table 1.

2.4.2 Health risk value calculation: In this study, six heavy metals $(\mathrm{Cr}, \mathrm{As}, \mathrm{Pb}, \mathrm{Cu}, \mathrm{Ni}$, and $\mathrm{Zn}$ ) were considered as noncarcinogenic, while $\mathrm{Cr}$ and As were considered as carcinogenic to humans. The non-carcinogenic hazard quotient (HQ), hazard index (HI) and carcinogenic risk (Risk) were estimated using the following formulas:

$$
\mathrm{HQ}=\mathrm{ADD} / \mathrm{RfD} \text {, }
$$


$\mathrm{HI}=\mathrm{HQ}_{\mathrm{i}}$,

Risk=ADD $\times \mathrm{SF}$,

Where $\operatorname{RfD}\left(\mathrm{mg} \mathrm{kg}^{-1} \mathrm{day}^{-1}\right)$ is the reference dose for each heavy metal, SF (mg kg ${ }^{-1}$ day $\left.{ }^{-1}\right)^{-1}$ the carcinogenic risk probability. The parameter values of $\operatorname{RfD}\left(\mathrm{mg} \mathrm{kg}^{-1}\right.$ day $\left.{ }^{-1}\right)$ and $\mathrm{SF}\left(\mathrm{mg} \mathrm{kg}^{-1} \text { day }^{-1}\right)^{-1}$ are shown in Table 6. HI is the total risk of non-carcinogenic heavy metals and is the sum of the HQs. When the value of HQ is more than 1, there is a high likelihood

\begin{tabular}{llcccc}
\hline Parameter & Meaning & Children & Adult & Unit & References \\
\hline C soil & Heavy metal concentration & & & & This study \\
IngR & Ingestion rate of soil & 200 & 100 & $\mathrm{mg} / \mathrm{kg}$ & (EPA, 2001) \\
InhR & Inhalation rate of soil & 5 & 20 & $\mathrm{mg} / \mathrm{day}$ & (ESG 2009) \\
PEF & Particle emission factor & $1.32 \mathrm{E}+09$ & $1.32 \mathrm{E}+09$ & $\mathrm{~m} 3 / \mathrm{day}$ & $($ EPA, 2001) \\
SA & Exposed skin surface area & 1800 & 5000 & $\mathrm{~m} 3 / \mathrm{kg}$ & (EPA, 2001) \\
SL & Skin adhesion factor & 1 & 1 & $\mathrm{mg} / \mathrm{cm}$ day & (EPA, 2001) \\
ABS & Dermal absorption factor & 0.001 & 0.001 & unitless & (EPA 1989) \\
ED & Exposure duration & 6 & 24 & years & (EPA, 2001) \\
EF & Exposure frequency & 350 & 350 & days/year & (ESG 2009) \\
BW & Average body weight & 15 & 55.9 & $\mathrm{~kg}$ & (ESG 2009) \\
AT & Average time & $365 * \mathrm{ED}$ & $365 * \mathrm{ED}$ & days & (EPA 1989) \\
\hline
\end{tabular}

Table 1. Parameter values in ADD calculation models of heavy metals.

\subsection{Data analysis}

We used the "MNS 5850: 2019" standard, non-contaminated soil test results, the average depth of heavy metals in Ulaanbaatar, and average heavy metal content in soil-polluted cities. The data were summarized using mean values, minimum values, maximum values, median, standard deviation and coefficient of variation (CV). Data analysis was carried out using Microsoft Excel (Microsoft Inc., USA) and the SPSS 19.0 software package for Windows. The spatial distribution of heavy metals and the PER were estimated using geostatistical analysis - IDW (spatial analysis tool) in GIS software (ArcGIS, version 10.4) (Santos-Francés et al., 2017), (Huang et al., 2017).

\subsection{Study area}

The study area is located southwest of Ulaanbaatar (E 106.8926, $\mathrm{N} 47.8913)$ at an altitude of 1245-1252 meter above sea level. It is a flat, open area with slight inclinations (1-2\%), 200 meters from the Tuul River. There are leather processing factories, a water treatment plant (WWTP) and a residential area. The center of the study area is located in the treatment plant (3.9 ha), and the leather processing factories are located in the west and north ( 8.5 ha). On the east side is the residential area (15.3 ha) and on the south side is the protected river area (Fig 1).

The prevailing wind direction is from the southeast, the average speed is $2.2 \mathrm{~m} / \mathrm{sec}$, and the number of days with wind is 260 . The average annual precipitation is $288 \mathrm{~mm}$. Most of the precipitation is in the warm season (July to August). The airborne particulate emissions (PM10) were measured at a level of 2.0 meters above ground level and they had an average of of adverse health effects, whereas when the value of HQ is lower than 1 , adverse health effects are considered unlikely. If Risk $<10^{-6}$, carcinogenic risk is considered to be negligible, and when Risk $>10^{-4}$ then there is a high risk of developing cancer in human beings. Values of Risk within a range from $10^{-6}$ to $10^{-4}$ are generally considered an acceptable risk to human beings (Guney et al., 2013).
$0.241-0.262 \mathrm{mg} / \mathrm{m}^{3}$ day. In addition, the chromium content is $0.157-0.189 \mu \mathrm{g} / \mathrm{m}^{3}$ per day, manganese is $0.074-0.054 \mu \mathrm{g} / \mathrm{m}^{3}$ per day. This exceeds the Mongolian national air quality standard technical requirements (MNS 4585:2016). When calculating the dust distribution with the AERMODE VIEW program, airborne dust levels increased from 200 to $300 \mathrm{~m}$ from the study area to $0.100-0.200 \mathrm{mg} / \mathrm{m}^{3}$.

The main soil types are alluvial soil with a gravelly, sandy, loamy texture. The alluvial soil texture is about 65.9-76.3\% gravel, 27.6-32.8 \% sand and the remaining part is silt and clay particles. Gravel and sandy soils are located in a saturated condition of 0.8-4.3 $\mathrm{m}$ in depth and are capable of free access to contaminated water. The groundwater level is about 3-4 meters deep. Alluvial soils are distributed throughout the treatment plant, with small pebbles on the soil surface, slight sand and salt accumulation, sparse vegetation cover and strong degradation.

This soil has the basic layers of A-B-BC-C. Layer A is $20 \mathrm{~cm}$ thick, dark brown with a sandy loam and mechanical components, varying gradually, $40 \%$ of which is small gravel plant roots, dense and with carbonate layer transition colors. Layer B is $30 \mathrm{~cm}$ thick, brown with a sandy loam and mechanical components, a small gravel density of $45 \%$ and varying brightness, with small, tight carbonate layers and transition stone plant roots. Layer BC is $50 \mathrm{~cm}$ thick, brown with a sandy mechanical component, $60 \%$ large pebbles, no vegetation roots, reddish orange, sparse density, carbonate, and stratigraphic transition stones. Layer $\mathrm{C}$ is $40 \mathrm{~cm}$ thick, brown yellow, silty loamy, no gravel, no plant roots, reddish brown with iron oxide, lightly dispersed, thin carbonate, and is a color transition layer. 


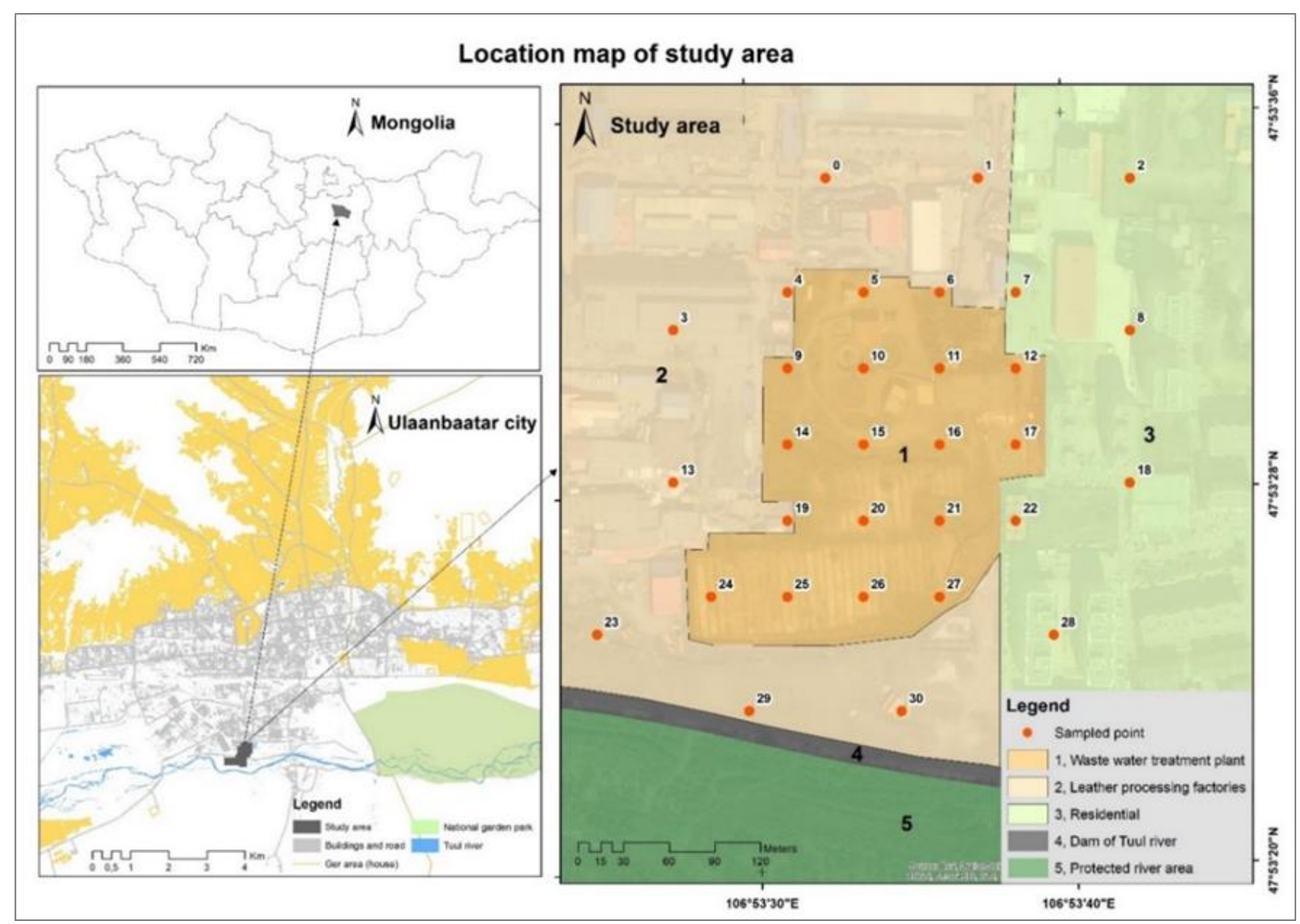

Figure 1. Location map of study area. (Industrial area, Ulaanbaatar, Mongolia)

\section{RESULTS AND DISCUSSION}

\subsection{Soil general properties}

The soil texture is mostly dominated by a coarse-grained sandy fraction in most layers. Across the survey area, the soil sand content is at a maximum of $69 \%$, silt $48 \%$, clay $19 \%$, minimum sand $32 \%$, dust $18 \%$, and clay $9 \%$. However, the texture of the soil layer $\mathrm{C}$ has a finer $(<0.05 \mathrm{~mm})$ silt and clay fraction dominated, or with muddy components. The soil $\mathrm{pH}$ varies from neutral (6.78) to strongly alkaline (8.09), with a slightly alkaline average of 7.53 . Furthermore, there is slightly acidic soil (6.11) in depth of $1.5 \mathrm{~m}$. The soil organic material level averages $2.85 \%$ in adjacent natural soil, averages $1.43 \%$ in soil around the wastewater treatment plant (WWTP), or the soil fertility rate is approximately twice as low. However, morganic content of the soil ranges $6.87 \%$ and $0.84 \%$. The content of soil carbonate $\left(\mathrm{CaCO}_{3}\right)$ is low in soil in the foreststeppe regions of Mongolia, mainly in the lower layers of the soil and in low concentrations. When topsoil samples contain carbonate, the soil will be degraded due to leaching effects. The results showed that soil samples around the treatment plant are on average of $6.55 \%$ carbonate, while the natural soil was at an average of $0.91 \%$. However, the total points had a maximum of $36.3 \%$. Soil EC (electrical conductivity) does not exceed 0.75 $\mathrm{dS} / \mathrm{m}$. Increasing EC reflects environmental pollution. The analysis of soil salinity showed a maximum of $18.02 \mathrm{dS} / \mathrm{m}$, minimum of 0.07 , and an average of $3.78 \mathrm{dS} / \mathrm{m}$, with typical soils having $0,123 \mathrm{dS} / \mathrm{m}$. As the salinization of the soil increases, the plants are less likely to grow. International classification of soil solubility of saline is less than $2.0 \mathrm{dS} / \mathrm{m}$, while $8.0 \mathrm{dS} / \mathrm{m}$ is highly salty soil (Table 2 ).

\begin{tabular}{|c|c|c|c|c|c|c|c|}
\hline \multirow{2}{*}{ Statistics } & \multirow{2}{*}{$\mathrm{pH}_{\mathrm{H} 2 \mathrm{O}}(1: 2.5)$} & \multirow{2}{*}{$\mathrm{CaCO}_{3}, \%$} & \multirow{2}{*}{ OM, \% } & \multirow{2}{*}{$\mathrm{EC}_{2.5} \mathrm{dS} / \mathrm{m}$} & \multicolumn{3}{|c|}{ Texture, $\%$} \\
\hline & & & & & Sand & Silt & Clay \\
\hline Mean & 7.53 & 6.80 & 1.43 & 3.81 & 58.64 & 27.54 & 13.82 \\
\hline Median & 7.53 & 3.15 & 1.07 & 2.77 & 59.09 & 27.80 & 13.64 \\
\hline Max & 8.09 & 36.35 & 6.87 & 18.02 & 68.87 & 37.04 & 20.88 \\
\hline Min & 6.78 & 0.00 & 0.84 & 0.32 & 46.93 & 17.56 & 9.18 \\
\hline Deep, $1.2 \mathrm{~m}$ & 6.11 & 0.36 & 1.440 & 3.140 & 32.3 & 48.3 & 19.4 \\
\hline Nature & 6.53 & 0.91 & 2.85 & 0.123 & 62.25 & 24.02 & 13.72 \\
\hline
\end{tabular}

Table 2. General soil properties 


\subsection{Heavy metal contamination}

The average concentrations of $\mathrm{Cr}, \mathrm{Ni}, \mathrm{Pb}, \mathrm{Zn}, \mathrm{Cu}$ and As were $1986.9,110.5,111.0,110.5,53.5,16.4 \mathrm{mg} / \mathrm{kg}$, respectively. As shown in Table 3, the mean and median concentrations of each heavy metal exceed the corresponding background value for soils in Mongolia. Percentage of samples exceeding standard ((Mongolian standard for toxic chemicals in soil, 2019)) value for each heavy metals following, Chromium $75 \%$, Arsenic 21.4 $\%$, Lead $3.6 \%$ and Copper $10.7 \%$.
Soil Calcium (Ca) content is 6 times higher than the base content (4.7\%) and Manganese (Mn) is 3 times higher (1.4 $\mathrm{mg} / \mathrm{kg}$ ). This is due to the chemicals used in leather processing factory and wastewater treatment. The study area soil $\mathrm{pH}$ is alkaline and Chromium $(\mathrm{Cr})$ of soil has a high probability of being oxidized to the hexavalent $\left(\mathrm{Cr}^{+6}\right)$ form and posing an additional health risk. The highest concentration of heavy metals in the soil is Chromium= with mean value $1986.9 \mathrm{mg} / \mathrm{kg}$ and reaches up to the $14760 \mathrm{mg} / \mathrm{kg}$.

\begin{tabular}{l|ccc|cccccc}
\hline \multirow{2}{*}{\multicolumn{1}{c|}{ Statistics }} & \multicolumn{3}{c|}{ Toxic heavy metals } & \multicolumn{5}{c}{ Toxic and bio-active metals } \\
\cline { 2 - 10 } & $\mathrm{Pb}$ & $\mathrm{As}$ & $\mathrm{Cr}$ & $\mathrm{Cu}$ & $\mathrm{Zn}$ & $\mathrm{Ni}$ & $\mathrm{V}$ & $\mathrm{Sr}$ & $\mathrm{Mo}$ \\
\hline Count & 28 & 28 & 28 & 28 & 28 & 28 & 28 & 28 & 7 \\
Mean & 33.2 & 16.4 & $\mathbf{1 9 8 6 . 9}$ & 53.5 & 110.5 & 13.6 & 38.8 & 361.5 & 3.7 \\
Max & 111.0 & 48.0 & 14760.0 & 392.0 & 224.0 & 27.0 & 102.0 & 782.0 & 7.0 \\
Min & 19.0 & 5.0 & 35.0 & 12.0 & 41.0 & 9.0 & 18.0 & 210.0 & 2.0 \\
Median & 29.5 & 11.5 & 687.5 & 33.0 & 90.5 & 12.5 & 36.5 & 301.5 & 3.0 \\
SD & 16.7 & 13.3 & 3328.4 & 69.9 & 52.3 & 4.7 & 15.3 & 145.2 & 1.7 \\
\hline Background & 21.0 & 9.5 & 84.5 & 15.5 & 55.5 & 13.5 & 47.0 & 241.0 & $<2.0$ \\
MNS 5850:2019 & 100.0 & 20.0 & 150.0 & 100.0 & 300.0 & 150.0 & 150.0 & 800.0 & 50.0 \\
\hline
\end{tabular}

Table 3. Descriptive statistics of heavy metals in soil, $\mathrm{mg} / \mathrm{kg}$

The adjacent unpolluted soil $\mathrm{pH}$ is neutral (Table 2). Soil heavy metals $(\mathrm{Cr}, \mathrm{Pb}, \mathrm{Mn}, \mathrm{Ni}$, and $\mathrm{Co})$ looks a low relation to the soil pH (Kabata-Pendias \& Pendias, 2001). This is evident that the process used by leather processing plants has changed soil raectioin from neutral to slightly alkaline. Alkaline soil is more likely to change Chromium compound of soil to he six-valent form. The leather factory used various chemicals disposed to the

soil and mixed with water and soil particles creating toxic compounds. The correlation coefficient lower than 0.36 indicating no significant correlation between toxic heavy metals and other macroelements $\mathrm{Al}, \mathrm{Mn}$ (Table 4), except for $\mathrm{Ca}$, Na with a correlation coefficient of $0.82,0.48$. Soil $\mathrm{Cr}$ has the potential to change to calcium chromate $\left(\mathrm{CaCrO}_{4}\right)$. Calcium magnesium guans feed on plants through hydroxylation through enzymes and organic acids.

\begin{tabular}{c|cccc|cccc}
\hline \multirow{2}{*}{ Heavy metals } & \multicolumn{4}{|c|}{ Alkaline metals } & \multicolumn{4}{c}{ Metals } \\
\cline { 2 - 9 } & $\mathrm{Ca}$ & $\mathrm{K}$ & $\mathrm{Mg}$ & $\mathrm{Na}$ & $\mathrm{Al}$ & $\mathrm{Fe}$ & $\mathrm{Ba}$ & $\mathrm{Mn}$ \\
\hline $\mathrm{As}$ & 0.69 & -0.73 & 0.34 & 0.19 & -0.17 & 0.14 & -0.45 & 0.08 \\
$\mathrm{Cr}$ & 0.82 & -0.71 & 0.10 & 0.48 & -0.36 & -0.25 & -0.74 & 0.05 \\
$\mathrm{~Pb}$ & 0.10 & -0.16 & 0.09 & -0.19 & 0.21 & 0.36 & 0.07 & 0.10 \\
$\mathrm{Cu}$ & 0.09 & -0.07 & 0.03 & 0.11 & 0.24 & 0.06 & -0.08 & 0.13 \\
\hline
\end{tabular}

Table 4. Correlation of soil heavy metals and microelements

Compared to the Mongolian soil standard (Mongolian standard for toxic chemicals in soil, 2019), the mean concentration of Chromium in the soil is 13.3 times higher than the maximum allowed value, exceeding 5.0 times toxic level, and 1.3 times higher than hazard level. Furthermore, in samples taken from the $1.2 \mathrm{~m}$ deep soil at the former waste area Chromium concentration is $161 \mathrm{mg} / \mathrm{kg}$, which exceeds the permissible level (Mongolian standard for toxic chemicals in soil, 2019) and evidence of Chromium migration to the deep soil and groundwater.

\begin{tabular}{llccccccl}
\hline \multirow{2}{*}{ City } & \multirow{2}{*}{ Country } & \multicolumn{7}{c}{ Metals in soil $(\mathrm{mg} / \mathrm{kg})$} \\
\cline { 3 - 7 } & & $\mathrm{As}$ & $\mathrm{Cr}$ & $\mathrm{Cu}$ & $\mathrm{Ni}$ & $\mathrm{Pb}$ & $\mathrm{Zn}$ & \multirow{2}{*}{ Reference } \\
\hline Study area & - & 16.4 & $\mathbf{1 9 8 6 . 9}$ & 53.3 & 13.6 & 33.2 & 110.5 & In study \\
Ulaanbaatar & Mongolia & 7.5 & 44.4 & 22.5 & 16.6 & 48.3 & 116.5 & (Batkhishig, et al., 2018) \\
Beijing & China & 7.6 & 50.3 & 31.6 & 23.9 & 29.7 & 76.5 & (Lin et al., 2018) \\
Moscow & Russia & - & 92.2 & 88.0 & 35.4 & 114.0 & 286.0 & (Kosheleva \& Nikiforova, \\
& & & & & & & & 2016) \\
Warsaw & Poland & - & 32.0 & 31.0 & 12.0 & 57.0 & 166.0 & (USEPA, 2006) \\
Stockholm & Sweden & - & 27.0 & 47.0 & 9.0 & 104.0 & 157.0 & (Poggio et al., 2009) \\
Madrid & Spain & - & 74.7 & 71.7 & 14.1 & 161.0 & 210.0 & (Manta et al., 2002)
\end{tabular}




\begin{tabular}{llccccccl} 
Bangkok & Thailand & - & 26.4 & 41.1 & 248 & 47.8 & 118.0 & (Shi et al., 2008) \\
Torino & Italy & - & 253 & 131.0 & 233 & 216.0 & 200.0 & (Madrid et al., 2007) \\
Manila & Philippines & - & 114 & 98.7 & 20.9 & 213.6 & 440.0 & (Manta et al., 2002) \\
Glasgow & UK & 9.0 & 52.0 & 62.0 & 41.0 & 195.0 & 178.0 & (Kasassi et al., 2008) \\
Hamburg & Germany & 23.0 & 95.4 & 146.6 & 52.5 & 218.2 & 516.0 & (Manta et al., 2002) \\
Mexico City & Mexico & - & 117 & 100.8 & 39.8 & 140.5 & 306.7 & $\begin{array}{l}\text { (Al-Khashman } \\
\text { Shawabeh, 2006) } \\
\text { Damascus }\end{array}$ \\
\hline
\end{tabular}

Table 5. Comparison of the content of heavy metals in international cities

\subsection{Pollution index}

In this study, the pollution index (PI), pollution load index (PLI), and potential ecological risk index (PER) were applied to assess the degree of heavy metals contamination in soils. The PIs calculated according to the background concentration of heavy metals in unpolluted soil around Ulaanbaatar, varied greatly (Fig. 2). the PI of all metals descending order is $\mathrm{Cr}>\mathrm{Zn}$ $>\mathrm{Cu}>\mathrm{Pb}>\mathrm{As}>\mathrm{Ni}$. Pollution index (PI) of $\mathrm{Cr}, \mathrm{Zn}, \mathrm{Cu}$, and $\mathrm{Pb}$ are higher with mean values of $28.44,1.57,1.48,1.26$ and wide range of PI for $\mathrm{Cr}$ 0.47-133.33, $\mathrm{Zn} \mathrm{0.63-3.11,} \mathrm{Cu} \mathrm{0.34-10.32,}$ and $\mathrm{Pb} 0.70-4.11$. These data clear indicate that Chromium (Cr) in soils showed high pollution. $\mathrm{Zn}, \mathrm{Cu}$, and $\mathrm{Pb}$ in urban soils showed medium pollution. As and $\mathrm{Ni}$ exhibited lower values, ranging from 0.21 to 2.00 and from 0.45 to 1.35 , with mean values of 0.70 and 0.68 respectively. The PLIs in all soil samples varied from 0.5 to 25.7 with a mean of 5.7 , indicating that the soils are very highly polluted by the heavy metals.

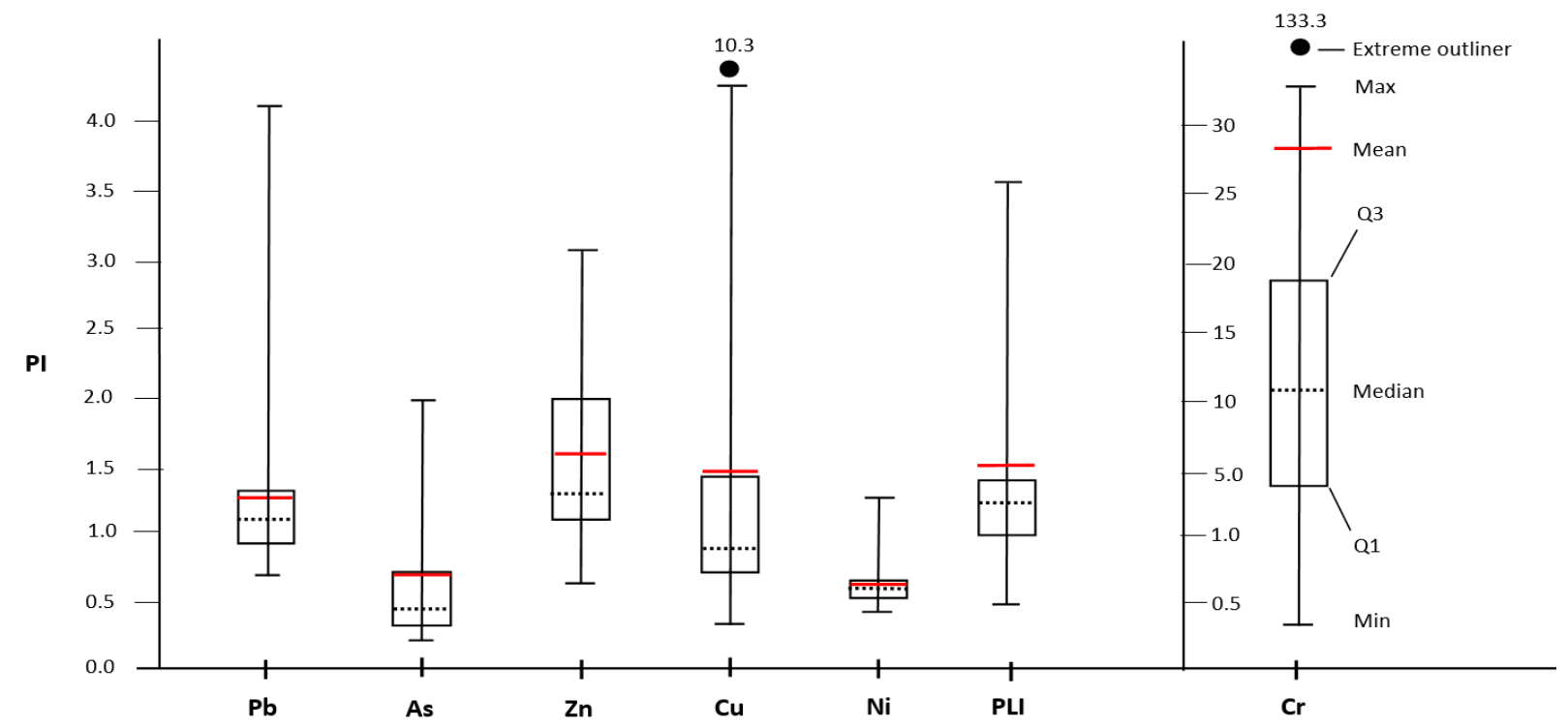

Figure 2. Box-plots of pollution index (PI) and pollution load index (PLI) for heavy metals

\subsection{Spatial distribution of heavy metals}

The spatial distribution of heavy metal concentrations is a useful aid to assess possible sources of enrichment and to identify hotspots with high metal concentrations (Zhao et al., 2014). The spatial distribution patterns of heavy metals $(\mathrm{Cr}, \mathrm{Pb}$, As, $\mathrm{Cu}, \mathrm{Zn}, \mathrm{Ni}$ ) in soils of WWTP and the leather processing factory area are represented in Fig. 3. The concentrations of heavy metals are indicated by colors intensity, red stands for high concentration while yellow stands for low concentration. The highest $\mathrm{Cr}$, As, and $\mathrm{Zn}$ concentrations associated with areas with wastewater treatment and leather factories. The similar spatial distribution trends of these metals indicated that they have the same source, which caused by disposals from leather factories. For $\mathrm{Cr}$, similar hotspots were found in the sludge accumulation points of the wastewater treatment plant area and southearn part of the study area. The mean value of $\mathrm{Cr}$ was much higher in these spots compared to other areas. Fig. 3 indicates $\mathrm{Pb}, \mathrm{Cu}$ and $\mathrm{Ni}$ had a different distribution pattern from other metals and the $\mathrm{Pb}$ and $\mathrm{Cu}$ hotspots were mainly in the northeast parts of the study area whichassociated solid waste collection sites (accumulator, electronic, car parts, etc.) The spatial distribution of heavy metals indicated the dominant role of industrial activities as major pollution sources. The leather production process can lead to extensive emission of dust and solid wastes containing toxic heavy metals, which are significant sources of heavy metal contamination for surrounding soils. 

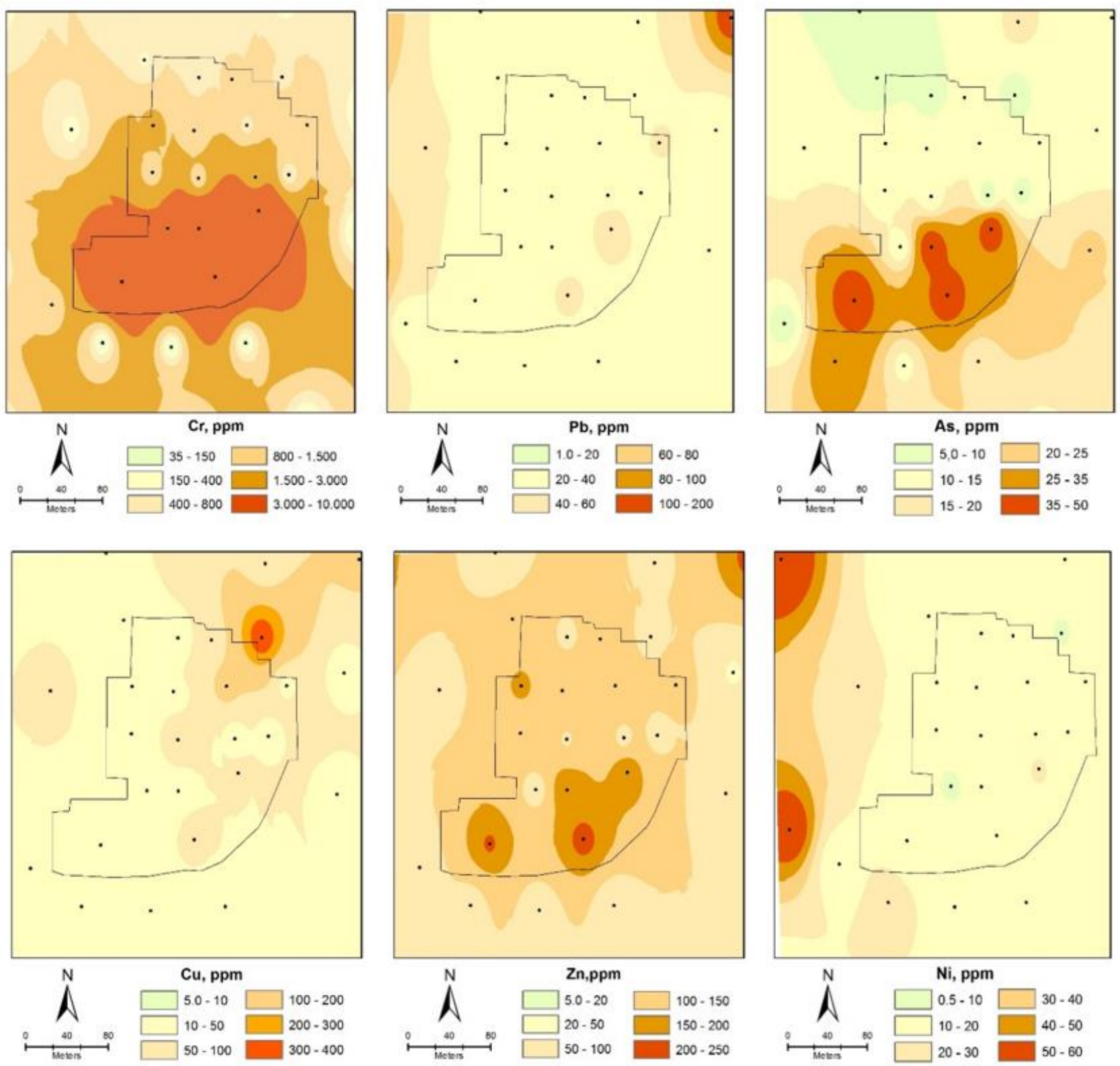

Figure 3. Spatial distribution of heavy metals in a WWTP and a leather processing factory area. The concentrations of heavy metals are indicated by green, yellow and red in each map. The red and orange depict high concentrations, yellow and green depict low concentrations.

\subsection{Potential ecological risk index}

Potential ecological risk (PER) represents the sensitivity of various biological communities to toxic substances and illustrates the potential ecological risk caused by hazardous elements (Islam et al., 2015), ( $\mathrm{Li}$ et al., 2014). The results for the PER assessment showed that the values of heavy metals can be ranked in the following order: $\mathrm{Cr}>\mathrm{Cu}>\mathrm{Pb}>\mathrm{As}>\mathrm{Ni}>\mathrm{Cd}$. The value of $\mathrm{Cr}$ (4266.46) was the highest, which suggests that there is a very high ecological risk in the study area (90\%) for this element. The range of PER for all sampling sites is between 81.46 and 4266.46 , indicating moderate to very high potential ecological risk. The mean values of PER of $\mathrm{Cu}$ (282.12), $\mathrm{Pb}$ (170.58), As (168.85) indicate a high ecological risk in the study area for these elements. The value PER of Ni (81.46) was lower than 160 but higher than 80 , which represents a moderate- considerable ecological risk. Cd (27.92) was lower than 40, which represents a low ecological risk. The results show that $\mathrm{Cr}$ was the largest contributor to PER in the industrial area of Ulaanbaatar topsoil. The spatial distribution characteristics of PER are shown in Figure 4. In the study area as a whole, the PER index values of $\mathrm{Cr}$ were higher than 320. Centrally, as well as south of the leather industrial areas, the PER index reached the maximum, which suggests that there was very high ecological risk in the area. The spatial distribution maps of PER for other heavy metals are green-yellow suggesting low ecological risk in these areas. The highest PERs of $\mathrm{Cr}$ were mainly related to the waste sludge from leather factories in study area. The highest PERs of $\mathrm{Pb}, \mathrm{Cu}$ and $\mathrm{Ni}$ were mainly related to solid waste collection, compared with the higher PERs of As, which mainly came from coal combustion exhaust. 

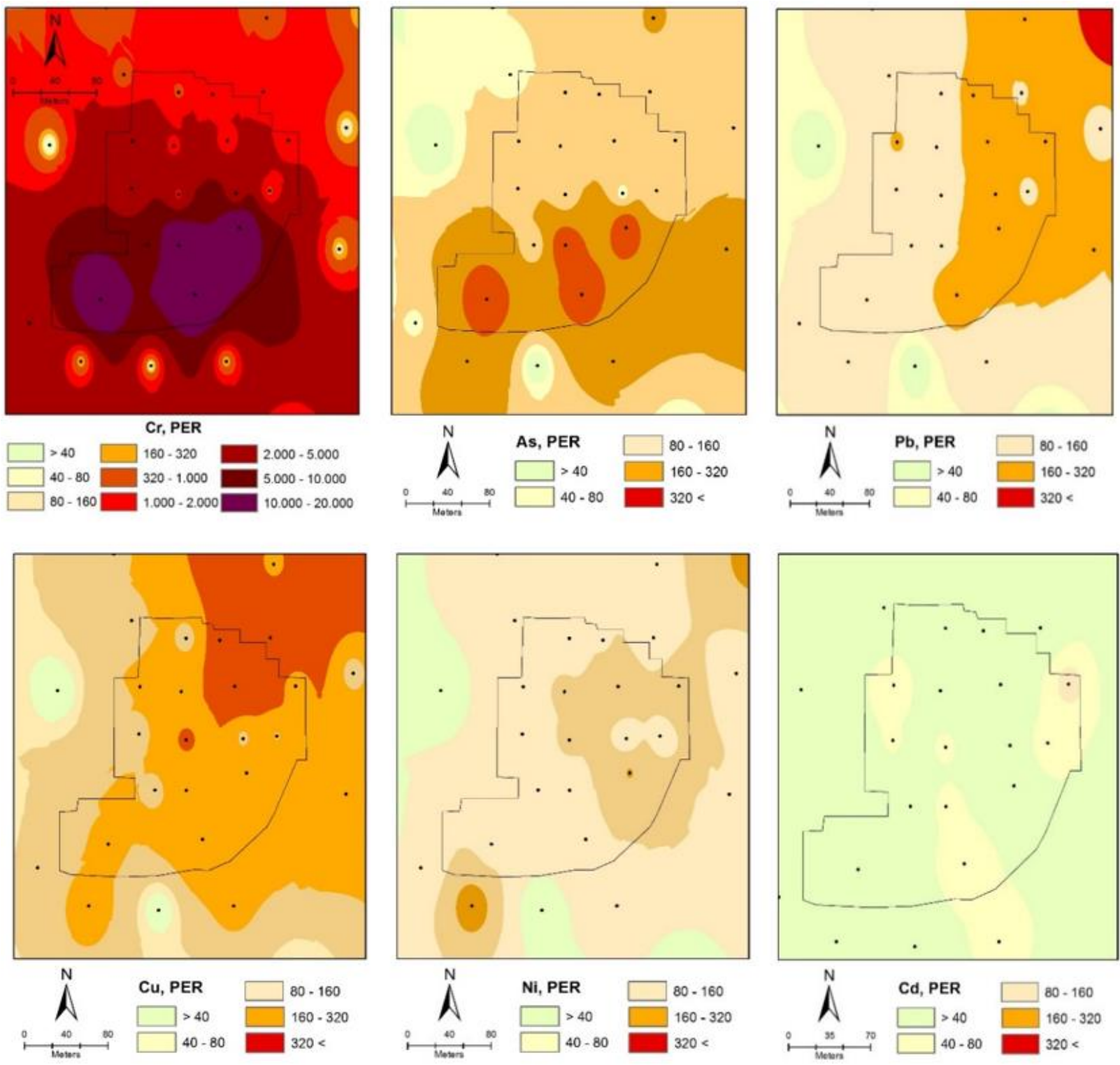

Figure 4. Spatial distribution of soil heavy metal PER coefficient of WWTP and a leather processing factory area of Ulaanbaatar. The spatial distribution characteristics of PER are indicated by green, yellow and red in each map. The brown, red and orange show high ecological risk, yellow and green show a low ecological risk.

\subsection{Human health risk assessment}

The assessment results of health risk due to heavy metal inhalation exposure in soils of leather factories Ulaanbaatar are shown in Table 6. The mean ADD values for children via ingestion of $\mathrm{Pb}, \mathrm{As}, \mathrm{Cr}$, and $\mathrm{Cu}$ were 4,36E-03, 2,16E-03, $2,73 \mathrm{E}-01$, and $7,21 \mathrm{E}-03$, while those via dermal contact were 2,39E-03, 1,18E-03, 1,49E-01, and 3,95E-03, and via inhalation were $8,26 \mathrm{E}-09,4,09 \mathrm{E}-09,5,17 \mathrm{E}-07$, and $1,36 \mathrm{E}-08$, respectively. The three different exposure pathways of metals for children decreased in the following order: dermal contact < ingestion < inhalation. HQing values for adults do not have the same trend as those for children. HQing is more likely to have an adverse effect on the health of the child, but for adults only the chromium HQ has a high impact on human health. However, the chromium HQ has a negative impact on adult health, which is related to the high concentration of chromium in the soil.
HQinh values for adults have the same trend as those for children. For most of the heavy metals, the contribution of HQdermal to HI (total risk of non-carcinogenic) was the highest, suggesting that dermal contact was the main exposure pathway that threatens human health. This result is also consistent with other authors (Chabukdhara \& Nema, 2013) (Wei et al., 2015) (Chonokhuu et al, 2019).

The HI values of heavy metals for children and adults decreased in the order of $\mathrm{Cu}<\mathrm{Pb}<\mathrm{As}<\mathrm{Cr}$ (Table 6). The $\mathrm{HI}$ values for almost all the metals were higher than 1 , indicating that there was a carcinogenic risk for children and adults. By comparing the HI values for children and adults, it can be concluded that children have a much higher non-carcinogenic risk from heavy metals in the city than adults.

There was a lack of the carcinogenic risks estimated for $\mathrm{Pb}$ and $\mathrm{Cu}$. The RI values in the urban soils of the industrial area were 
$1,73 \mathrm{E}+01(\mathrm{Cr})$, and 5,01E-02 (As) for children and 2,89E+01 (Cr) and 8,36E-02 (As) for adults (Table 6).

RI values for adults were also higher compared to children. The RI values of two metals (Cr, As) for children and adults were higher than $10^{-4}$, indicating high risk of developing cancer in human beings (Guney et al., 2013).

The human health risk assessment is a powerful tool for distinguishing toxic heavy metals and exposure routes of most concerns in urban environments.

However, the calculated risk of both non-carcinogenic and carcinogenic metal exposure from urban soil was influenced by several uncertainty factors. The exposure factors and parameters for health risk assessment of heavy metals were derived from the EPA (2001), which produced an exposure handbook that may, however, not be suitable for the Mongolian context. Up to the present, there have been no assessment guidance and exposure factors for a health risk assessment in Mongolia. In addition, the total contents of heavy metals were used for health risk assessments in this study. The risk assessments based on the total concentrations of heavy metals in soils may

\begin{tabular}{lc|cccc} 
the total concentrations & of heavy & metals & in soils may & & \\
\multicolumn{7}{c}{ Factor } & & Pb & As & Cr & \\
\hline ADD ing & Child & $4,36 \mathrm{E}-03$ & $2,16 \mathrm{E}-03$ & $2,73 \mathrm{E}-01$ & $7,21 \mathrm{E}-03$ \\
& Adult & $5,85 \mathrm{E}-04$ & $2,90 \mathrm{E}-04$ & $3,66 \mathrm{E}-02$ & $9,68 \mathrm{E}-04$ \\
ADD inh & Child & $8,26 \mathrm{E}-09$ & $4,09 \mathrm{E}-09$ & $5,17 \mathrm{E}-07$ & $1,36 \mathrm{E}-08$ \\
& Adult & $8,86 \mathrm{E}-09$ & $4,38 \mathrm{E}-09$ & $5,54 \mathrm{E}-07$ & $1,46 \mathrm{E}-08$ \\
ADD dermal & Child & $2,39 \mathrm{E}-03$ & $1,18 \mathrm{E}-03$ & $1,49 \mathrm{E}-01$ & $3,95 \mathrm{E}-03$ \\
& Adult & $1,07 \mathrm{E}-02$ & $5,29 \mathrm{E}-03$ & $6,68 \mathrm{E}-01$ & $1,77 \mathrm{E}-02$ \\
\hline HQ ing & Child & $1,25 \mathrm{E}+00$ & $7,20 \mathrm{E}+00$ & $9,09 \mathrm{E}+01$ & $1,80 \mathrm{E}-01$ \\
& Adult & $1,67 \mathrm{E}-01$ & $9,65 \mathrm{E}-01$ & $1,22 \mathrm{E}+01$ & $2,42 \mathrm{E}-02$ \\
HQ inh & Child & $2,35 \mathrm{E}-06$ & $1,32 \mathrm{E}-05$ & $1,81 \mathrm{E}-02$ & $3,40 \mathrm{E}-07$ \\
& Adult & $2,52 \mathrm{E}-06$ & $1,42 \mathrm{E}-05$ & $1,94 \mathrm{E}-02$ & $3,65 \mathrm{E}-07$ \\
HQ dermal & Child & $4,51 \mathrm{E}+00$ & $9,85 \mathrm{E}+00$ & $2,49 \mathrm{E}+03$ & $3,29 \mathrm{E}-01$ \\
& Adult & $2,02 \mathrm{E}+01$ & $4,40 \mathrm{E}+01$ & $1,11 \mathrm{E}+04$ & $1,47 \mathrm{E}+00$ \\
\hline HI & Child & $5,75 \mathrm{E}+00$ & $1,70 \mathrm{E}+01$ & $2,58 \mathrm{E}+03$ & $5,09 \mathrm{E}-01$ \\
& Adult & $2,03 \mathrm{E}+01$ & $4,50 \mathrm{E}+01$ & $1,11 \mathrm{E}+04$ & $1,50 \mathrm{E}+00$ \\
Risk & Child & - & $5,01 \mathrm{E}-02$ & $1,73 \mathrm{E}+01$ & - \\
& Adult & - & $8,36 \mathrm{E}-02$ & $2,89 \mathrm{E}+01$ & - \\
\hline C (mg/kg) & & 34,1 & 16,9 & 2133,2 & 56,4 \\
RfD ing & & $3,50 \mathrm{E}-03$ & $3,00 \mathrm{E}-04$ & $3,00 \mathrm{E}-03$ & $4,00 \mathrm{E}-02$ \\
RfD inh & $3,52 \mathrm{E}-03$ & $3,10 \mathrm{E}-04$ & $2,86 \mathrm{E}-05$ & $4,02 \mathrm{E}-02$ \\
RfD dermal & & $5,30 \mathrm{E}-04$ & $1,20 \mathrm{E}-04$ & $6,00 \mathrm{E}-05$ & $1,20 \mathrm{E}-02$ \\
SF inh & & - & $1,50 \mathrm{E}+01$ & $4,10 \mathrm{E}+01$ & - \\
\hline
\end{tabular}

Table 6. ADDs (mg/kg/day) and health risk for each element and exposure pathway.

\section{CONCLUSION}

Ulaanbaatar city leather processing factory and wastewater treatment plant (WWTP) operations on surrounding soil leads to contamination of chromium $(\mathrm{Cr})$ and other heavy metals (As, $\mathrm{Pb}, \mathrm{Cu}, \mathrm{Zn}$ ). According to the Pollution index of soils, $\mathrm{Cr}$ has high pollution and $\mathrm{Zn}, \mathrm{Cu}$ and $\mathrm{Pb}$ have middle pollution levels. The potential ecological risk (PER) of $\mathrm{Cr}, \mathrm{Cu}, \mathrm{Pb}$ and $\mathrm{As}$ indicated high ecological risk in the study area. The RI values of two metals ( $\mathrm{Cr}$, As) contribute to a high risk of developing cancer in humans. Heavy metal contamination can spread as soil particles are swept away from contaminated areas by wind and automobiles. Therefore, leather processing factory and overestimate the actual hazards they pose to humans. Chromium toxicity directly depends on its valence state, either $\mathrm{Cr}$ (III) or $\mathrm{Cr}$ (VI). Cr (III) is less toxic, while Cr (VI) is highly toxic to biota. The $\mathrm{Cr}$ (VI) has been determined to be a human carcinogen which equate to evidence of carcinogenic risk (Sun et al., 2015) (Moghtaderi et al., 2018). In addition, the health effects of $\mathrm{Cr}$ can be overestimated due to a very high concentration in several sampling sites. Additionally, $\mathrm{Cu}, \mathrm{Pb}$, and $\mathrm{Zn}$ in urban soils may also pose a public health risk, considering the high concentration of these elements present in soils of the areas studied. Further study is needed to evaluate the human health risk of other toxic metals and to explain the reasons for the higher health risks caused mainly by $\mathrm{Cr}$ in the areas studied. The major pollutants of heavy metals in study sites are chromium and zinc and the pollution severity follows the following sequence: $\mathrm{Cr}>\mathrm{Zn}>\mathrm{Cu}>\mathrm{Pb}>\mathrm{As}>\mathrm{Ni}$. The source of pollution is primarily related to leather processing factory. 
Jordan. Environmental Pollution, 140(3), 387-394. https://doi.org/10.1016/j.envpol.2005.08.023

Asfaw, T. B., Tadesse, T. M., \& Ewnetie, A. M. (2017). Determination of Total Chromium and Chromium Species in Kombolcha Tannery Wastewater, Surrounding Soil, and Lettuce Plant Samples, South Wollo, Ethiopia. Advances in Chemistry, 2017, 1-7. https://doi.org/10.1155/2017/6191050

Batjargal, T., Yang, J. S., Kim, D. H., \& Baek, K. (2011). Removal characteristics of cd(II), cu(II), pb(II), and zn(II) by natural mongolian zeolite through batch and column experiments. Separation Science and Technology, 46(8), 13131320. https://doi.org/10.1080/01496395.2010.551394

Batkhishig, O., Oyunbat, P., Bolormaa, T., Zoljargal, K., Ikhbayar, D., Elbegzaya, G., Zolzaya, M. (2018). The Ulaanbaatar city Soil Pollution. Ulaanbaatar: Mongolian Academy of Sciences (in Mongolian).

Chabukdhara, M., \& Nema, A. K. (2013). Heavy metals assessment in urban soil around industrial clusters in

Ghaziabad, India: Probabilistic health risk approach. Ecotoxicology and Environmental Safety, 87, 57-64. https://doi.org/10.1016/j.ecoenv.2012.08.032

Chen, H., Teng, Y., Lu, S., Wang, Y., \& Wang, J. (2015). Contamination features and health risk of soil heavy metals in China. Science of the Total Environment, 512-513, 143-153. https://doi.org/10.1016/j.scitotenv.2015.01.025

Chen TB, Zheng YM, Chen H, Zheng GD. 2004. Background concentrations of soil heavy metals in Beijing. Environ Sci. 25 (1):117-122.

Chonokhuu, S., Batbold, C., Chuluunpurev, B., Battsengel, E., Dorjsuren, B., \& Byambaa, B. (2019). Contamination and health risk assessment of heavy metals in the soil of major cities in Mongolia. International Journal of Environmental Research and Public Health, 16(14). https://doi.org/10.3390/ijerph16142552

EPA. (2001). Baseline Human Health Risk Assessment. Vasquez Boulevard and 1-70 Superfund Site Denver, Denver (Co). United States Environmental Protection Agency.

Erdenesaikhan, N., Altangerel, D., Batmunkh, E., \& Enkhbayar, B. (2017). Heavy Metal Pollution Near a Tannery in Ulaanbaatar, Mongolia. Journal of Health \& Pollution., 7(16), 2-11. doi:10.5696/2156-9614-7.16.2

Forum, R. A., \& Agency, U. S. E. P. (1986). Guidelines for Carcinogen Risk Assessment. 51(September), 33992-34003.

Gallagher, F. J., Pechmann, I., Bogden, J. D., Grabosky, J., \& Weis, P. (2008). Soil metal concentrations and vegetative assemblage structure in an urban brownfield. Environmental Pollution, 153(2), $351-361$ https://doi.org/10.1016/j.envpol.2007.08.011

Guney, M., Welfringer, B., De Repentigny, C., \& Zagury, G. J. (2013). Children's exposure to mercury-contaminated soils: Exposure assessment and risk characterization. Archives of Environmental Contamination and Toxicology, 65(2), 345-355. https://doi.org/10.1007/s00244-013-9891-7

Hakanson, L. (1980). An ecological risk index for aquatic pollution control.a sedimentological approach. Water Research, 14(8), 975-1001. https://doi.org/10.1016/0043-1354(80)901438

Huang, S., Yuan, C., Li, Q., Yang, Y., Tang, C., Ouyang, K., \& Wang, B. (2017). Distribution and risk assessment of heavy metals in soils from a typical $\mathrm{Pb}-\mathrm{Zn}$ mining area. Polish Journal of Environmental Studies, 26(3), 1105-1112. https://doi.org/10.15244/pjoes/68424

Islam, S., Ahmed, K., Habibullah-Al-Mamun, M., \& Masunaga, S. (2015). Potential ecological risk of hazardous elements in different land-use urban soils of Bangladesh. Science of the Total Environment, 512-513, 94-102. https://doi.org/10.1016/j.scitotenv.2014.12.100

Jaishankar, M., Tseten, T., Anbalagan, N., Mathew, B. B., \& Beeregowda, K. N. (2014). Toxicity, mechanism and health effects of some heavy metals. Interdisciplinary Toxicology, 7(2), 60-72. https://doi.org/10.2478/intox-2014-0009

Kabata-Pendias, A., \& Pendias, H. (2001). Biogeochemistry of trace elements. In Trace Elements in Soils and Plants, Third Edition (Vol. 2nd, Issue 2). https://doi.org/10.1201/b10158-25

Kasassi, A., Rakimbei, P., Karagiannidis, A., Zabaniotou, A., Tsiouvaras, K., Nastis, A., \& Tzafeiropoulou, K. (2008). Soil contamination by heavy metals: Measurements from a closed unlined landfill. Bioresource Technology, 99(18), 8578-8584. https://doi.org/10.1016/j.biortech.2008.04.010

Kosheleva, N. E., \& Nikiforova, E. M. (2016). Long-term dynamics of urban soil pollution with heavy metals in Moscow. Applied and Environmental Soil Science, 2016. https://doi.org/10.1155/2016/5602795

Li, Z., Ma, Z., van der Kuijp, T. J., Yuan, Z., \& Huang, L. (2014). A review of soil heavy metal pollution from mines in China: Pollution and health risk assessment. Science of the Total Environment, 468-469, 843-853. https://doi.org/10.1016/j.scitotenv.2013.08.090

Lin, M., Li, S., Sun, X., Yang, S., \& Li, J. (2018). Heavy metal contamination in green space soils of Beijing, China. Acta Agriculturae Scandinavica Section B: Soil and Plant Science, 68(4), 291-300. https://doi.org/10.1080/09064710.2017.1395474

Madrid, F., Reinoso, R., Florido, M. C., Díaz Barrientos, E., 
Ajmone-Marsan, F., Davidson, C. M., \& Madrid, L. (2007). Estimating the extractability of potentially toxic metals in urban soils: A comparison of several extracting solutions.

Environmental Pollution, 147(3), 713-722. https://doi.org/10.1016/j.envpol.2006.09.005

Manta, D. S., Angelone, M., Bellanca, A., Neri, R., \& Sprovieri, M. (2002). Heavy metals in urban soils: A case study from the city of Palermo (Sicily), Italy. Science of the Total Environment, 300(1-3), 229-243. https://doi.org/10.1016/S00489697(02)00273-5

Means, B. (n.d.). Guidance for Superfund' Human Health Evaluation Manual ( Part A) Interim Final.

Moghtaderi, T., Mahmoudi, S., Shakeri, A., \& Masihabadi, M. H. (2018). Heavy metals contamination and human health risk assessment in soils of an industrial area, Bandar Abbas-South Central Iran. Human and Ecological Risk Assessment, 24(4), 1058-1073. https://doi.org/10.1080/10807039.2017.1405723

Möller, A., Müller, H. W., Abdullah, A., Abdelgawad, G., \& Utermann, J. (2005). Urban soil pollution in Damascus, Syria: Concentrations and patterns of heavy metals in the soils of the Damascus Ghouta. Geoderma, 124(1-2), 63-71. https://doi.org/10.1016/j.geoderma.2004.04.003

Mongolian standard for toxic chemicals in soil. (2019). MNS 5850:2019 Soil quality. Soil pollutants permissible value. (in Mongolian)

Nriagu J O, Nieboer E. (1988). Production and uses of chromium. In: Nriagu JO, Nieboer E, editors. Chromium in natural and human environments. New York: Wiley. 81-104.

Of, O., \& Services, E. (2009). Environmental Site Assessment Guidelines Office of Environmental Services Ohio Department of Transportation Office of Environmental Services 1980 West Broad Street. 43223(April).

Poggio, L., Vrščaj, B., Schulin, R., Hepperle, E., \& Ajmone Marsan, F. (2009). Metals pollution and human bioaccessibility of topsoils in Grugliasco (Italy). Environmental Pollution, 157(2), 680-689. https://doi.org/10.1016/j.envpol.2008.08.009

Santos-Francés, F., Martínez-Graña, A., Zarza, C. Á., Sánchez, A. G., \& Rojo, P. A. (2017). Spatial distribution of heavy metals and the environmental quality of soil in the Northern Plateau of Spain by geostatistical methods. International Journal of Environmental Research and Public Health, 14(6). https://doi.org/10.3390/ijerph14060568

Shi, G., Chen, Z., Xu, S., Zhang, J., Wang, L., Bi, C., \& Teng, J. (2008). Potentially toxic metal contamination of urban soils and roadside dust in Shanghai, China. Environmental Pollution,
Exposure and Toxicity. Current Environmental Health Reports, 2(3), 295-303. https://doi.org/10.1007/s40572-015-0054-z

Taylor, K. G., \& Owens, P. N. (2009). Sediments in urban river basins: A review of sediment-contaminant dynamics in an environmental system conditioned by human activities. Journal of Soils and Sediments, 9(4), 281-303. https://doi.org/10.1007/s11368-009-0103-z

U.S. EPA. (2011). Exposure Factors Handbook; EPA, Environmental Protection Agency. U.S. Environmental Protection Agency, Washington, DC EPA/600/R-090/052F, September, 1-1466. https://doi.org/EPA/600/R-090/052F

USEPA. (2006). Memorandum: Guidance for 2006 Assessment, Listing and Reporting Requirements Pursuant to Sections 303(d), 305(b) and 314 of the Clean Water Act. 1, 1-89.

Wei, X., Gao, B., Wang, P., Zhou, H., \& Lu, J. (2015). Pollution characteristics and health risk assessment of heavy metals in street dusts from different functional areas in Beijing, China. Ecotoxicology and Environmental Safety, 112, 186-192. https://doi.org/10.1016/j.ecoenv.2014.11.005

Wong, C. S. C., Li, X., \& Thornton, I. (2006). Urban environmental geochemistry of trace metals. Environmental Pollution, 142(1), 1-16. https://doi.org/10.1016/j.envpol.2005.09.004

Ying, L., Shaogang, L., \& Xiaoyang, C. (2016). Assessment of heavy metal pollution and human health risk in urban soils of a coal mining city in East China. Human and Ecological Risk Assessment, 22(6), 1359-1374. https://doi.org/10.1080/10807039.2016.1174924

Zhao, L., Xu, Y., Hou, H., Shangguan, Y., \& Li, F. (2014). Source identification and health risk assessment of metals in urban soils around the Tanggu chemical industrial district, Tianjin, China. Science of the Total Environment, 468-469, 654-662. https://doi.org/10.1016/j.scitotenv.2013.08.094

Zhu, F. X., \& Qi, W. F. (2007). 1-error linear complexity of pnperiodic sequences over Fp. Dianzi Yu Xinxi Xuebao/Journal of Electronics and Information Technology, 29(9), 2222-2225. 